Journal reference: World Neurosurg. (2018) 112:e675-e682.

https://doi.org/10.1016/j.wneu.2018.01.124

\title{
Analysis of Four Scoring Systems for the Prognosis of Patients with Metastasis of the Vertebral Column
}

Péter Pollner PhD. (3) /divided $1^{\text {st }}$ author/, Anna Horváth MD., PhD (4) /divided $1^{\text {st }}$ author/, Tamás Mezei (2), Péter Banczerowski MD., PhD. (1, 2) Gábor Czigléczki MD. $(1,2)$

1: National Institute of Clinical Neurosciences, Budapest, Hungary

2: Department of Neurosurgery, Semmelweis University, Budapest, Hungary

3: MTA-ELTE Statistical and Biological Physics Research Group

4: 3rd Department of Internal Medicine, Semmelweis University, Budapest, Hungary

Corresponding author:

Gábor Czigléczki MD

National Institute of Clinical Neurosciences, Hungary, Budapest

1145, Amerikai út 57.

Phone: +3614679300

Email: gczigleczki@gmail.com

\section{$\underline{\text { Key words }}$}

spinal metastases, prognostic factors, prognosis scoring systems,

\section{Abbreviations and Acronyms}

CI: Confidence Interval

CR: Consistency rate

KM: Kaplan-Meier

OS: Overall survival 


\section{Abstract}

OBJECTIVE: Metastatic spinal diseases are common health problems and there is no consensus on the appropriate treatment of metastases in several conditions. Using clinical measures (e.g., survival time and functional status), prognosis prediction systems advise on the appropriate interventions. The aim of this article is to assess and compare 4 widely used scoring systems (revised Tokuhashi, Tomita, van der Linden, and modified Bauer scores) on a single-center cohort.

METHODS: A retrospective study was designed of 329 patients who were subjected to surgery because of meta-static spinal diseases. Subpopulations according to the classifications of the 4 scoring systems were identified. The overall survival was calculated with the KaplanMeier formula. The difference between the survival curves of subpopulations was analyzed with log-rank tests. The consistency rates for the 4 scoring systems are calculated as well.

RESULTS: The follow-up period was 8 years. The median survival time was 222 days. The overall survival of prognostic categories in 3 scoring systems was significantly different from each other, but we found no differences between the categories of the van der Linden system. In this cohort, the revised Tokuhashi system gave the best approximation for survival, with a mean predictive capability $60.5 \%$.

CONCLUSIONS: The evaluation of 4 standard scoring systems showed that 3 were selfconsistent, although none of systems was able to predict the survival in our cohort. Based on the predictive capability, the revised Tokuhashi system may provide the best predictions with careful examination of individual cases. 


\section{Introduction}

The vertebral column is the third most common site for metastasis after pulmonary and hepatic secondary lesions and the most common site for skeletal lesions. [1,2] It affects $7 \%$ of patients with oncologic diseases. [3] Symptoms caused by tumors could be pain or motoric or sensory deficits caused by spinal cord or nerve root compression. [4-7] Optimal treatment should take into account the patient's general condition and life expectancy. Patients expected to have long survival benefit from invasive surgical treatment or from high-dosage radiation therapy or from a combination of these 2 treatments. In contrast, patients expected to have shorter survival because of their poor general condition may benefit from more conservative solutions (low-dosage radiation therapy, palliative or minimally invasive surgical options, or supportive care). [4,8-10]

To make evidence-based choices for optimal care, several prognosis predicting systems have been created for treatment of metastatic spinal tumors. [11] These systems combine risk factors with different weights and classify patients into different prognostic groups. For each prognosis category, a treatment is proposed based on the predicted survival. The aim of this article is to analyze 4 prognostic scoring systems of patients with spinal metastasis. These scoring systems are used in spinal neurosurgical practice to determine the best treatment choices in these oncologic cases. 


\section{Methods}

$\underline{\text { Patient database and examined prognostic systems }}$

The patient cohort for the analysis was compiled from the electronic medical record at the National Institute of Clinical Neuroscience, in Budapest, Hungary. We identified 382 operations in 337 patients who underwent surgery because of vertebral metastasis, and we had information about the date of last surgery for 329 patients. The operations were performed from December 2007 to December 2015. The status of the patient or the date of death was

checked in December 2016. The only inclusion criterion was a positive diagnosis with metastatic spinal lesions and surgical treatment of the lesions. Some of the patients (n 1/4 38) had more than 1 surgical intervention ( 31 patients with 2 interventions and 7 patients with 3 interventions; none of the patients had $>3$ interventions).

The 4 examined scoring systems were the following:

- Tokuhashi et al. [12-16] reported a scoring system in 1989, and after 16 years, in 2005, the same group reported a revised version (Table 1).

- The system by Tomita and Kawahara [17] was constructed from a retrospective analysis in 2001 (Table 2)

- Bauer et al[18]. reported their system in 1995. Later, Leithner et al. [19] and Wibmer et al. [20] modified the Bauer score, omitting the pathologic fractures as a risk factor, and they reported better prediction values (Table 3)

- The scoring system by van der Linden et al. [21] was reported in 2005 (Table 4)

We collected all data to score patients by these systems. Demographic and baseline clinical variables of interest included sex and age at time of surgery. Baseline functional status was measured by Karnofsky Performance Status. Further data about the status of the patient was recorded such as main clinical symptoms, presence of motoric or sensory deficit, Frankel scores, extraspinal bony metastases, and metastases in the internal organs. About the surgical intervention, we extracted the following factors: affected vertebral levels, steps of intervention, postoperative condition, and the length of hospital stay. Each patient history consisted of data about the metastasis (categorized by primary site of origin), histologic diagnoses, and other comorbidities. 


\section{$\underline{\text { Statistical analysis }}$}

Survival was calculated from the date of the last operation and either from the date of death or from the latest follow-up. In cases of death, we had access only to the date, and the cause of death was not registered in our database. We created survival curves by using a Kaplan-Meier (KM) formula and compared them with a log-rank test. $\mathrm{P}$ values $<0.05$ were considered significant. We calculated the consistency rates (CRs) between the predicted prognosis and the actual survival in our cohort (1-KM or $\mathrm{KM}$ as appropriate) following the definition by Tokuhashi et al. [15] for the evaluation of predicted survival by the scoring system calculated from data of the cohort. Calculations were made by $\mathrm{R}$ software version 3.0.2 (R Foundation for Statistical Computing, Vienna, Austria) [22]. 


\section{Results}

$\underline{\text { Survival and oncologic data of the population }}$

We identified 337 patients, 199 (59.1\%) male and 138 (40.9\%) female, with a mean age of 63 years (range, $15 \mathrm{e} 88$ years). Overall survival (OS) was calculated by the KM formula. Median OS (amount of time when $50 \%$ of the patients have died) was 222 days, and the $95 \%$ confidence interval (CI) ranged from 175 to 274 days. The prevalence of the most common primary tumors was distributed as follows: lung (n 1/4 84, 24.9\%), multiple myeloma (n $1 / 4$ $38,11.3 \%$ ), breast (n $1 / 430,8.9 \%$ ), cancer of unknown primary site (n $1 / 430,8.9 \%$ ), kidney (n 1/4 26, 7.7\%), prostate (n 1/4 22, 5.6\%), and colorectal (n 1/4 22, 6.5\%). Sixty-six patients had no internal metastasis (19.6\%) and 53 had no other skeletal metastasis (15.7\%).

\section{Examinations of the prognosis systems}

\section{Revised Tokuhashi score}

Because in the revised Tokuhashi score (Table 1), many tumor types with different malignancies and prognosis form a group ( 2 points, "other" category), we had to categorize our patients with different primary tumor types. We sscored the patients according to histologic similarities and oncologic treatment possibilities (Table 5). We also used this method for the Tomita system (Table 6). The modified Bauer and van der Linden scores did not need any modification because they are accurate about which types of tumors receive points and they do not provide examples. We compared the survival of groups of patients in the 3 prognostic categories. We found that these categories are significantly different according to survival; the log-rank test reported $\mathrm{P}<0.001$. We tested each category to check the deviation from the other 2 categories. Each category was found to be different, but with various $\mathrm{P}$ values: conservative group (0-8 points), $\mathrm{P}<0.001$; palliative group (9-11 points), $\mathrm{P}<0.001$; and excisional group (12-15 points), $\mathrm{P}=0.013$ (Figure 1). We calculated the CRs for each prognostic category as well (Table 7). The most accurate prediction was observed in the palliative category, in which the system predicted with 95\% CI the real OS time with 57\% to $74 \%$ probability. On average, the system predicted with an accuracy of $60.5 \%$ in our cohort.

\section{Tomita score}

We also had to make some specifications to the classification of Tomita primary tumor categories (Table 2). Our extended scoring method of Tomita primary tumor categories is 
shown in Table 6, which is categorized by histologic similarities and oncologic treatment possibilities. The prognostic categories were significantly different according to survival $(\mathrm{P}<$ 0.001). We tested all 4 categories separately as well, to establish whether they were different from the rest of the population. All were significantly different: long-term (2e3 points), $\mathrm{P}<$ 0.001; midterm (4e5 points), P 1/4 0.007; short-term (6e7 points), $\mathrm{P}<0.001$; and terminal (8e10 points), P 1/4 0.008. The KM curves are shown in Figure 2. Next, we examined the accuracy of the predicted survival (Table 8 ). The CRs in the last column of Table 8 show that there is a serious difference between our findings and the predicted survival of the Tomita system. For this cohort, the OS was predicted correctly by this system with an average accuracy of only $28.8 \%$ of the patients, calculated as the average of the last column of Table 8.

\section{Modified Bauer score}

This scoring system separated the cohort into significantly different groups $(\mathrm{P}<0.001)$ according to OS. Each group was different from the rest of the population as well: the short survival group ( $0-1$ point), $\mathrm{P}=0.0013$; moderate survival group ( 2 points $), \mathrm{P}<0.001$; and long survival group (3-4 points), $\mathrm{P}<0.001$ (see Figure 3 for $\mathrm{KM}$ curves). The predictive value of this system is shown in Table 9. This system could not be regarded as accurate (29.5\% of global prediction ability), especially for the moderate group, which resulted in a low CR. OS was predicted correctly for only $6.3 \%$ of the patients with a modified Bauer score of 2 .

\section{Van der Linden score}

This system was the only one in which the prognostic groups were not significantly different (Figure 4). We examined the prediction ability of this system as well (Table 10). Although the van der Linden system did not separate groups of patients with significantly different KM curves, its average prediction ability $(48.6 \%)$ is better than that of the modified Bauer and Tomita values. 


\section{Discussion}

Scoring systems were introduced in neurosurgical practice to determine the best treatment decisions in metastatic spinal diseases. The aim of our study was to compare 4 well-known systems and analyze them to identify which presents the best prediction results.

The revised Tokuhashi scoring system [15] (Table 1) is widely used in clinical practice and receives much attention. In a restricted cohort of patients with only hepatocellular carcinoma, Chen et al. [23] also compared the predictive ability of the 4 scoring systems. The main result of their study agrees with that of the present analysis: the revised Tokuhashi system has the best ability to predict survival (Figure 1). However, there are notable variances among the exact performances of the revised Tokuhashi scores in the literature. When Tokuhashi et al. [16] investigated the ability of their system, they found an $88 \%$ predictive probability, Yamashita et al. [24] reported 79\%, and Hessler et al. [25] reported 67\%, when the calculations were based on cohorts of $<100$ patients. Eap at al. [26] reported the reproducibility and usefulness of the system in a 260-patient population and found a weighted Cohen k coefficient of 0.41 (95\% CI, 0.33-0.50). Our results confirm the findings in the literature. For the conservative category, the survival for $62 \%$ of the patients matched the prediction of the system, for the palliative category, this value was $65 \%$, and for the excisional group, it was $54 \%$. On average, the system has $60.8 \%$ predicting ability. This value is near the mean in the literature (i.e., 66\%).[27-29] We found also that the scoring system separates the groups of patients with different prognosis with a very strong significance, and the conservative category was most significantly separated from the rest of the population (Table 7).

Bauer et al. [30] showed that the Tomita scoring system (Table 2) separates patients into groups with good and bad prognosis. We found similar results by showing that the survival curves of the categories of the Tomita system are significantly different from each other (Figure 2). The most separated group was the one with patients with long-term prognosis (Table 8). According to our calculations, the Tomita system predicted the survival of patients in our cohort with a low probability (28.8\%). The analysis of the modified Bauer score 18 (Table 3) also affirms the findings in the literature. The prognostic groups of this system were significantly different (Figure 3 ) and 2 groups (the good and the moderate) were significantly different from the rest of the population (Table 9). We calculated the predictive ability of the Bauer system as well and found a low value $(29.5 \%)$. 
van der Linden et al. [21] examined their own van der Linden system (Table 4) and reported a $73 \%$ predictive probability. In the cohort in our study, the van der Linden score did not achieve such high results $(48.6 \%)$. Furthermore, we did not find significant differences between the survival curves of the groups of this system (Figure 4, Table 10).

The scoring systems have their own errors and pitfalls, [7,11,25,31,32] but they are widely accepted in clinical practice. [7,11,24,26,27,33-36] The results are shown in Table 11. Examination of our population showed that the revised Tokuhashi system performs the best prediction results and the results of other prognostic systems (Tomita system and modified Bauer system but not the van der Linden score) are also in accordance with previously reported findings. However, this study is limited by its retrospective design and usually there are large variations in intervention responses because of unrecorded genetic, habitual, and personal features of patients that can modify the results; therefore, the conclusion and consequences must be cautiously considered. To the best of our knowledge, there are no any bigger single-center studies in the literature, so we hope that our research will contribute to knowledge about prognosis predicting scoring systems. 


\section{Conclusion}

The aim of this article was to analyze 4 prognostic scoring systems of patients with spinal metastasis and determine which presents the best prediction results.

According to our findings, the Tomita and Bauer scores separated the classes of patients with good and moderate prognosis, and patients with poor condition were easily identified with the revised Tokuhashi scoring system. Concerning the ability of predicting average survival, the revised Tokuhashi system was the most reliable. However, we found considerable differences between the predictive values of the scoring systems compared with results in the literature.

Spinal metastatic diseases remain a serious and challenging surgical problem, but early diagnosis and sufficient treatment may prevent serious complications and allow longer survival. Using reliable prognostic scoring systems, the surgical decision can be determined more precisely. We believe that our results could be a possible base for multicentric prospective study in the future to determine the best treatment protocol for patients with spinal metastases.

Conflict of interest statement: This project received partial funding from the Novo Nordisk Foundation Interdisciplinary Synergy Programme (grant NNF15OC0016584) and from an EFOP-3.6.3-VEKOP-16-2017-00009 scholarship.

\section{Figure legends}

$\underline{\text { Table list }}$

Table 1. The revised Tokuhashi score

Table 2. The Tomita score

Table 3. The modified Bauer score

Table 4. The van der Linden score

Table 5. Extended scoring method for revised Tokuhashi primary tumor categories

Table 6. Extended scoring method for Tomita primary tumor categories 
Table 7. Predictive values of the revised Tokuhashi system Extended scoring method for Tomita primary tumor categories

Table 8. Predictive values of the Tomita system

Table 9. Predictive values of the modified Bauer system

Table 10. Predictive values of the van der Linden system

\section{$\underline{\text { Figure list }}$}

Fig. 1. Kaplan-Meier curves of the revised Tokuhashi system's prognosis categories

Fig. 2. Kaplan-Meier curves of the Tomita system's prognosis categories

Fig. 3. Kaplan-Meier curves of the modified Bauer system's prognosis categories

Fig. 4. Kaplan-Meier curves of the van der Linden system's prognosis categories 


\section{$\underline{\text { References }}$}

1. Choi D, Crockard A, Bunger C, Harms J, Kawahara N, Mazel C, et al. Review of metastatic spine tumour classification and indications for surgery: the consensus statement of the Global Spine Tumour Study Group. Eur Spine J. 2010;19:215-222.

2. Aaron AD: The management of cancer metastatic to bone. JAMA 1994, 272(15):1206-1209.

3. Jacobs WB, Perrin RG: Evaluation and treatment of spinal metastases: an overview. Neurosurg Focus 2001, 11(6):e10.

4. Donthineni R: Diagnosis and staging of spine tumors. Orthop Clin North Am 2009, 40(1):1-7, v.

5. Ecker RD, Endo T, Wetjen NM, Krauss WE: Diagnosis and treatment of vertebral column metastases. Mayo Clin Proc 2005, 80(9):1177-1186.

6. Hosono N, Ueda T, Tamura D, Aoki Y, Yoshikawa H: Prognostic relevance of clinical symptoms in patients with spinal metastases. Clin Orthop Relat Res 2005(436):196-201.

7. Zoccali C, Skoch J, Walter CM, Torabi M, Borgstrom M, Baaj AA: The Tokuhashi score: effectiveness and pitfalls. Eur Spine J 2016, 25(3):673-678.

8. Walker MP, Yaszemski MJ, Kim CW, Talac R, Currier BL: Metastatic disease of the spine: evaluation and treatment. Clin Orthop Relat Res 2003(415 Suppl):S165-175.

9. Meyer SA, Singh H, Jenkins AL: Surgical treatment of metastatic spinal tumors. Mt Sinai J Med 2010, 77(1):124-129.

10. Bartels RH, van der Linden YM, van der Graaf WT: Spinal extradural metastasis: review of current treatment options. CA Cancer J Clin 2008, 58(4):245-259.

11. Tokuhashi Y, Uei H, Oshima M, Ajiro Y: Scoring system for prediction of metastatic spine tumor prognosis. World J Orthop 2014, 5(3):262-271.

12. Tokuhashi Y, Kawano H, Ohsaka S, Matsuzaki H, Toriyama S: [A scoring system for preoperative evaluation of the prognosis of metastatic spine tumor (a preliminary report)]. Nihon Seikeigeka Gakkai Zasshi 1989, 63(5):482-489.

13. Tokuhashi Y, Matsuzaki H, Toriyama S, Kawano H, Ohsaka S: Scoring system for the preoperative evaluation of metastatic spine tumor prognosis. Spine (Phila Pa 1976) 1990, 15(11):1110-1113.

14. Tokuhashi Y, Matsuzaki H, Kawano H, Sano S: [The indication of operative procedure for a metastatic spine tumor: a scoring system for the preoperative evaluation of the prognosis]. Nihon Seikeigeka Gakkai Zasshi 1994, 68(5):379-389.

15. Tokuhashi Y, Matsuzaki H, Oda H, Oshima M, Ryu J: A revised scoring system for preoperative evaluation of metastatic spine tumor prognosis. Spine (Phila Pa 1976) 2005, 30(19):2186-2191.

16. Tokuhashi Y, Ajiro Y, Umezawa N: Outcome of treatment for spinal metastases using scoring system for preoperative evaluation of prognosis. Spine (Phila Pa 1976) 2009, 34(1):69-73.

17. Tomita K, Kawahara N, Kobayashi T, Yoshida A, Murakami H, Akamaru T: Surgical strategy for spinal metastases. Spine (Phila Pa 1976) 2001, 26(3):298-306.

18. Bauer HC, Wedin R: Survival after surgery for spinal and extremity metastases. Prognostication in 241 patients. Acta Orthop Scand 1995, 66(2):143-146.

19. Leithner A, Radl R, Gruber G, Hochegger M, Leithner K, Welkerling H, Rehak P, Windhager R: Predictive value of seven preoperative prognostic scoring systems for spinal metastases. Eur Spine J 2008, 17(11):1488-1495. 
20. Wibmer C, Leithner A, Hofmann G, Clar H, Kapitan M, Berghold A, Windhager R: Survival analysis of $\mathbf{2 5 4}$ patients after manifestation of spinal metastases: evaluation of seven preoperative scoring systems. Spine (Phila Pa 1976) 2011, 36(23):1977-1986.

21. van der Linden YM, Dijkstra SP, Vonk EJ, Marijnen CA, Leer JW, Dutch Bone Metastasis Study G: Prediction of survival in patients with metastases in the spinal column: results based on a randomized trial of radiotherapy. Cancer 2005, 103(2):320328.

22. R Core Team (2013). R: A language and environment for statistical computing. R Foundation for Statistical Computing, Vienna, Austria. URL http://www.r-/ project.org/. 23. Chen H, Xiao J, Yang X, Zhang F, Yuan W: Preoperative scoring systems and prognostic factors for patients with spinal metastases from hepatocellular carcinoma. Spine (Phila Pa 1976) 2010, 35(23):E1339-1346.

24. Yamashita T, Siemionow KB, Mroz TE, Podichetty V, Lieberman IH: A prospective analysis of prognostic factors in patients with spinal metastases: use of the revised Tokuhashi score. Spine (Phila Pa 1976) 2011, 36(11):910-917.

25. Hessler C, Vettorazzi E, Madert J, Bokemeyer C, Panse J: Actual and predicted survival time of patients with spinal metastases of lung cancer: evaluation of the robustness of the Tokuhashi score. Spine (Phila Pa 1976) 2011, 36(12):983-989.

26. Eap C, Tardieux E, Goasgen O, Bennis S, Mireau E, Delalande B, Cvitkovik F, Baussart B, Aldea S, Jovenin $\mathrm{N}$ et al: Tokuhashi score and other prognostic factors in 260 patients with surgery for vertebral metastases. Orthop Traumatol Surg Res 2015, 101(4):483-488.

27. Luksanapruksa P, Buchowski JM, Hotchkiss W, Tongsai S, Wilartratsami S, Chotivichit A: Prognostic factors in patients with spinal metastasis: a systematic review and meta-analysis. Spine $J 2016$.

28. Quraishi NA, Manoharan SR, Arealis G, Khurana A, Elsayed S, Edwards KL, Boszczyk BM: Accuracy of the revised Tokuhashi score in predicting survival in patients with metastatic spinal cord compression (MSCC). Eur Spine J 2013, 22 Suppl 1:S21-26. 29. Bollen L, Wibmer C, Van der Linden YM, Pondaag W, Fiocco M, Peul WC, Marijnen CA, Nelissen RG, Leithner A, Dijkstra SP: Predictive Value of Six Prognostic Scoring Systems for Spinal Bone Metastases: An Analysis Based on 1379 Patients. Spine (Phila Pa 1976) 2016, 41(3):E155-162.

30. Bauer H, Tomita K, Kawahara N, Abdel-Wanis ME, Murakami H: Surgical strategy for spinal metastases. Spine (Phila Pa 1976) 2002, 27(10):1124-1126.

31. Oliveira MF, Barros Bde A, Rotta JM, Botelho RV. Tokuhashi Scoring System has limited applicability in the majority of patients with spinal cord compression secondary to vertebral metastasis. Arq Neuropsiquiatr. 2013;71:798-801.

32. Gakhar H, Swamy GN, Bommireddy R, Calthorpe D, Klezl Z. A study investigating the validity of modified Tokuhashi score to decide surgical intervention in patients with metastatic spinal cancer. Eur Spine J. 2013;22:565568.

33. Papastefanou S, Alpantaki K, Akra G, Katonis P. Predictive value of Tokuhashi and Tomita scores in patients with metastatic spine disease. Acta Orthop Traumatol Turc. 2012;46:50-56. 
34. Wang M, Bunger CE, Li H, Wu C, Hoy K, Niedermann B, et al. Predictive value of Tokuhashi scoring systems in spinal metastases, focusing on various primary tumor groups: evaluation of 448 patients in the Aarhus spinal metastases database. Spine (Phila Pa 1976). 2012;37:573-582.

35. Aoude A, Amiot LP. A comparison of the modified Tokuhashi and Tomita scores in determining prognosis for patients afflicted with spinal metastasis. Can J Surg. 2014;57:188-193.

36. Petteys RJ, Spitz SM, Rhee J, Goodwin CR, Zadnik PL, Sarabia-Estrada R, et al. Tokuhashi score is predictive of survival in a cohort of patients undergoing surgery for renal cell carcinoma spinal metastases. Eur Spine J. 2015;24:21422149.

Tables

Table 1. The Revised Tokuhashi Score 


\begin{tabular}{|l|l|}
\hline Predictive Factors & Point(s) \\
\hline $\begin{array}{l}\text { General condition (Karnofsky } \\
\text { Performance Status, \%) }\end{array}$ & 0 \\
\hline Poor (10-40) & 1 \\
\hline Moderate (50-70) & 2 \\
\hline Good (80-100) & 0 \\
\hline Number of extraspinal bone foci & 1 \\
\hline$>=3$ & 2 \\
\hline $1-2$ & 1 \\
\hline 0 & 1 \\
\hline $\begin{array}{l}\text { Number of metastases in the } \\
\text { vertebral body }\end{array}$ & 2 \\
\hline$>=3$ & 1 \\
\hline 2 & 0 \\
\hline 1 & 2 \\
\hline Metastasis to the major internal \\
organs
\end{tabular}




\begin{tabular}{|c|c|}
\hline Predictive Factors & Point(s) \\
\hline Rectum & 4 \\
\hline Thyroid, breast, prostate, arcinoid & 5 \\
\hline Palsy & \\
\hline Frankel A, B (complete) & 0 \\
\hline Frankel C, D (incomplete) & 1 \\
\hline Frankel E (none) & 2 \\
\hline Prognostic Categories (Points) & Interpretation \\
\hline $0-8$ & $\begin{array}{l}85 \% \text { lives }<6 \text { months }-->\text { conservative } \\
\text { treatment or palliative surgery }\end{array}$ \\
\hline $9-11$ & $\begin{array}{l}73 \% \text { lives }>6 \text { months (and } 30 \%>1 \text { year)-- } \\
>\text { palliative surgery or (exceptionally) } \\
\text { excisional surgery }\end{array}$ \\
\hline $12-15$ & 95\% lives $>1$ year --> excisional surgery \\
\hline
\end{tabular}

Table 2 The Tomita Score 


\begin{tabular}{|c|c|}
\hline Predictive Factors & Point(s) \\
\hline \multicolumn{2}{|l|}{ Primary tumor } \\
\hline Slow growth (e.g., breast, prostate, thyroid) & 1 \\
\hline Moderate growth (e.g., kidney, uterus) & 2 \\
\hline $\begin{array}{l}\text { Rapid growth (e.g., lung, liver, stomach, } \\
\text { colon, primary unknown) }\end{array}$ & 4 \\
\hline \multicolumn{2}{|l|}{ Primary tumor } \\
\hline No visceral metastasis & 0 \\
\hline Treatable & 2 \\
\hline Untreatable & 4 \\
\hline \multicolumn{2}{|l|}{ Bone metastasis (including spine) } \\
\hline Solitary/isolated & 1 \\
\hline Multiple & 2 \\
\hline Prognostic Categories (Points) & Interpretation \\
\hline $2-3$ & $\begin{array}{l}\text { Long-term local control (mean } \\
\text { survival } 50 \text { months) --> wide or } \\
\text { marginal excision }\end{array}$ \\
\hline $4-5$ & $\begin{array}{l}\text { Mid-term local control (mean } \\
\text { survival } 23.5 \text { months) --> marginal } \\
\text { or intralesional excision }\end{array}$ \\
\hline $6-7$ & $\begin{array}{l}\text { Short-term palliation } \quad \text { (mean } \\
\text { survival } 15 \text { months) }-->\text { palliative } \\
\text { surgery }\end{array}$ \\
\hline $8-10$ & $\begin{array}{l}\text { Terminal care (mean survival } 6 \\
\text { months) --> supportive care, no } \\
\text { surgery }\end{array}$ \\
\hline
\end{tabular}


Table 3. The Modified Bauer Score

\begin{tabular}{|l|l|}
\hline Predictive Factors & Point(s) \\
\hline No visceral metastasis & 1 \\
\hline No lung cancer & 1 \\
\hline $\begin{array}{l}\text { Primary tumor = breast, kidney, } \\
\text { lymphoma, multiple myeloma }\end{array}$ & 1 \\
\hline 1 solitary skeletal metastasis & 1 \\
\hline Prognostic Categories (Points) & Interpretation \\
\hline $0-1$ & 4.8 monthsesupportive care, no surgery \\
\hline 2 & \begin{tabular}{l}
18.2 monthseshort-term palliation, dorsal \\
surgery \\
$28.4 \quad$ monthsemid-term local control, \\
\hline $3-4$
\end{tabular} \\
\hline
\end{tabular}

Table 4 The van der Linden Score 


\begin{tabular}{|l|l|}
\hline Predictive Factors & Point(s) \\
\hline Karnofsky Performance Status & 2 \\
\hline $80-100$ & 1 \\
\hline $50-70$ & 0 \\
\hline $20-40$ & \\
\hline Primary tumor & 3 \\
\hline Breast & 2 \\
\hline Prostate & 1 \\
\hline Lung & 0 \\
\hline Other & 1 \\
\hline Visceral metastasis & 0 \\
\hline No & Interpretation \\
\hline Yes & 4.8 monthseconservative therapy \\
\hline Prognostic Categories (Points) & 13.1 monthsepalliative surgery \\
\hline $0-3$ & 18.3 monthseexcisional surgery \\
\hline $4-5$ & \\
\hline 6 & \\
\hline
\end{tabular}

Table 5. Extended Scoring Method for Revised Tokuhashi Primary Tumor Categories 


\begin{tabular}{|c|c|}
\hline Points & Primary Site of Cancer (Revised Tokuhashi) \\
\hline 0 & $\begin{array}{l}\text { Lung, osteosarcoma, chondrosarcoma, stomach, bladder, esophagus, } \\
\text { pancreas, angiosarcoma, melanoma, mesothelioma, neuroendocrine } \\
\text { carcinoma }\end{array}$ \\
\hline 1 & Liver, gallbladder, unidentified \\
\hline 2 & $\begin{array}{l}\text { Others, germ cell tumors, other epithelial carcinomas (e.g., tonsils and } \\
\text { larynx), hematologic malignancies, parotis }\end{array}$ \\
\hline 3 & Kidney, uterus, cervix, ovarium \\
\hline 4 & Colon, rectum \\
\hline 5 & $\begin{array}{l}\text { Thyroid, breast, prostate, carcinoid tumor, osteoblastoma, chondroma, } \\
\text { hemangioma }\end{array}$ \\
\hline
\end{tabular}

Table 6. Extended Scoring Method for Tomita Primary Tumor Categories

\begin{tabular}{|l|l|}
\hline Points & \begin{tabular}{l} 
Primary Tumor (Tomita) \\
\hline 1
\end{tabular} \\
\hline 2 & $\begin{array}{l}\text { Slow growth (e.g., breast, prostate, thyroid, osteoblastoma, } \\
\text { chondroma, hemangioma) } \\
\text { other epithelial carcinomas [e.g., tonsils and larynx], hematologic } \\
\text { malignancies, parotis) }\end{array}$ \\
\hline 4 & $\begin{array}{l}\text { Rapid growth (e.g., lung, liver, stomach, colon, rectum, primary } \\
\text { unknown, osteosarcoma, chondrosarcoma, extraskeletal Ewing } \\
\text { sarcoma, giant cell bone tumor, angiosarcoma, gallbladder } \\
\text { carcinoma, bladder carcinoma, melanoma, mesothelioma, } \\
\text { pancreas, neuroendocrine carcinoma, esophagus) }\end{array}$ \\
\hline
\end{tabular}


Table 7. Predictive Values of the Revised Tokuhashi System, KM=Kaplan-Meier

\begin{tabular}{|l|l|l|l|}
\hline Point Category (Points) & $\begin{array}{l}\text { Prognosis } \\
\text { (days) }\end{array}$ & $\begin{array}{l}\text { Number of } \\
\text { Patients }\end{array}$ & $\begin{array}{l}\text { Consistency Rate (1-KM or KM) } \\
\text { (95\% Confidence Interval) }\end{array}$ \\
\hline Conservative (0-8) & $<180$ & 138 & $1-\mathrm{KM}: 0.62(0.529 \mathrm{e} 0.693)$ \\
\hline Palliative (9-11) & $>180$ & 127 & KM: $0.653(0.575-0.741)$ \\
\hline Excisional (12-15) & $>365$ & 59 & KM: $0.541(0.422-0.693)$ \\
\hline
\end{tabular}

Table 8. Predictive Values of the Tomita System

\begin{tabular}{|l|l|l|l|}
\hline $\begin{array}{l}\text { Point } \\
\text { Category }\end{array}$ & $\begin{array}{l}\text { Prognosis } \\
\text { (days) }\end{array}$ & $\begin{array}{l}\text { Number of } \\
\text { Patients }\end{array}$ & $\begin{array}{l}\text { Consistency Rate (Kaplan-Meier) } \\
(95 \% \text { Confidence Interval) }\end{array}$ \\
\hline $2-3$ & $>50 \times 30$ & 97 & $0.414(0.313-0.549)$ \\
\hline $4-5$ & $>23.5 \times 30$ & 105 & $0.153(0.093-0.252)$ \\
\hline $6-7$ & $>15 \times 30$ & 84 & $0.190(0.120-0.301)$ \\
\hline $8-10$ & $>6 \times 30$ & 41 & $0.394(0.266-0.584)$ \\
\hline
\end{tabular}

Table 9. Predictive Values of the Modified Bauer System

\begin{tabular}{|l|l|l|l|}
\hline $\begin{array}{l}\text { Point } \\
\text { Category }\end{array}$ & $\begin{array}{l}\text { Prognosis } \\
\text { (days) }\end{array}$ & $\begin{array}{l}\text { Number } \\
\text { Patients }\end{array}$ & $\begin{array}{l}\text { of } \\
(95 \% \text { Confidence Interval) }\end{array}$ \\
\hline $0-1$ & $>4.8 \times 30$ & 26 & $0.461(0.305-0.699)$ \\
\hline 2 & $>18.2 \times 30$ & 108 & $0.063(0.029-0.136)$ \\
\hline $3-4$ & $>28.4 \times 30$ & 195 & $0.363(0.295 e 0.446)$ \\
\hline
\end{tabular}

Table 10. Predictive Values of the van der Linden System 


\begin{tabular}{|l|l|l|l|}
\hline $\begin{array}{l}\text { Point } \\
\text { Category }\end{array}$ & $\begin{array}{l}\text { Prognosis } \\
\text { (days) }\end{array}$ & $\begin{array}{l}\text { Number } \\
\text { Patients }\end{array}$ & $\begin{array}{l}\text { of } \\
(95 \% \text { Confidence Interval) }\end{array}$ \\
\hline $0-3$ & $>4.8 \times 30$ & 263 & $0.595(0.539-0.658)$ \\
\hline $4-5$ & $>13.1 \times 30$ & 54 & $0.407(0.295-0.562)$ \\
\hline 6 & $>18.3 \times 30$ & 11 & $0.455(0.212-0.973)$ \\
\hline
\end{tabular}

Table 11. Evaluation of the Scoring Systems According to the Literature 


\begin{tabular}{|c|c|c|c|c|c|}
\hline Reference & $\begin{array}{l}\text { Publicati } \\
\text { on Date }\end{array}$ & $\begin{array}{l}\text { Type of } \\
\text { Study }\end{array}$ & $\begin{array}{l}\text { Number of Cases/ } \\
\text { Number of Articles } \\
\text { Identified }\end{array}$ & $\begin{array}{l}\text { Investigate } \\
\text { d Systems }\end{array}$ & Conclusion \\
\hline $\begin{array}{l}\text { Zoccali et } \\
\text { al. [7] }\end{array}$ & $\begin{array}{l}\text { April } \\
2015\end{array}$ & Review & $1686 /-$ & $\begin{array}{l}\text { Revised } \\
\text { Tokuhashi }\end{array}$ & $\begin{array}{l}\text { The mean } \\
\text { predicting ability } \\
\text { is } 63 \% \text {. It needs } \\
\text { critical } \\
\text { assessment, } \\
\text { especially of } \\
\text { patients with } 12 \\
\text { months survival }\end{array}$ \\
\hline $\begin{array}{l}\text { Tokuhashi } \\
\text { et al. [11] }\end{array}$ & July 2014 & Review & $-/ 236$ & $\begin{array}{l}\text { Tokuhashi, } \\
\text { revised } \\
\text { Tokuhashi, } \\
\text { Tomita, } \\
\text { Bauer, van } \\
\text { der } \\
\text { Linden, } \\
\text { Rades, } \\
\text { Katagiri }\end{array}$ & $\begin{array}{l}\text { Effectiveness and } \\
\text { pitfalls of all of } \\
\text { these systems } \\
\text { discussed }\end{array}$ \\
\hline $\begin{array}{l}\text { Yamashit } \\
\text { a et al. } \\
{[24]}\end{array}$ & $\begin{array}{l}\text { May } \\
2011\end{array}$ & $\begin{array}{l}\text { Prospec } \\
\text { tive }\end{array}$ & $85 /-$ & $\begin{array}{l}\text { Revised } \\
\text { Tokuhashi }\end{array}$ & $\begin{array}{l}79 \% \text { of mean } \\
\text { predicting ability }\end{array}$ \\
\hline $\begin{array}{l}\text { Hessler et } \\
\text { al. [25] }\end{array}$ & $\begin{array}{l}\text { May } \\
2011\end{array}$ & $\begin{array}{l}\text { Retrosp } \\
\text { ective }\end{array}$ & $81 /-$ & $\begin{array}{l}\text { Revised } \\
\text { Tokuhashi }\end{array}$ & $\begin{array}{l}67.1 \% \text { of mean } \\
\text { predicting ability }\end{array}$ \\
\hline $\begin{array}{l}\text { Eap et al. } \\
{[26]}\end{array}$ & $\begin{array}{l}\text { March } \\
2015\end{array}$ & $\begin{array}{l}\text { Retrosp } \\
\text { ective }\end{array}$ & $260 /-$ & $\begin{array}{l}\text { Revised } \\
\text { Tokuhashi }\end{array}$ & $\begin{array}{l}\text { They confirm the } \\
\text { validity of the } \\
\text { system }\end{array}$ \\
\hline $\begin{array}{l}\text { Luksanapr } \\
\text { uksa et al. } \\
\text { [27] }\end{array}$ & $\begin{array}{l}\text { May } \\
2017\end{array}$ & $\begin{array}{l}\text { Review } \\
\text { and } \\
\text { meta- } \\
\text { analysi } \\
\text { s }\end{array}$ & $-/ 3959$ & $\begin{array}{l}\text { Revised } \\
\text { Tokuhashi, } \\
\text { Tomita, } \\
\text { Bauer, van } \\
\text { der Linden }\end{array}$ & $\begin{array}{l}\text { Effectiveness and } \\
\text { pitfalls of all of } \\
\text { these systems } \\
\text { discussed }\end{array}$ \\
\hline
\end{tabular}




\begin{tabular}{|c|c|c|c|c|c|}
\hline Reference & $\begin{array}{l}\text { Publicati } \\
\text { on Date }\end{array}$ & $\begin{array}{l}\text { Type of } \\
\text { Study }\end{array}$ & $\begin{array}{l}\text { Number of Cases/ } \\
\text { Number of Articles } \\
\text { Identified }\end{array}$ & $\begin{array}{l}\text { Investigate } \\
\text { d Systems }\end{array}$ & Conclusion \\
\hline $\begin{array}{l}\text { Oliveira et } \\
\text { al. [31] }\end{array}$ & $2013^{\text {July }}$ & $\begin{array}{l}\text { Prospec } \\
\text { tive }\end{array}$ & $60 /-$ & $\begin{array}{l}\text { Revised } \\
\text { Tokuhashi }\end{array}$ & $\begin{array}{l}\text { The system is not } \\
\text { useful in guiding } \\
\text { treatment }\end{array}$ \\
\hline $\begin{array}{l}\text { Gakhar et } \\
\text { al. [32] }\end{array}$ & $\begin{array}{l}\text { August } \\
2013\end{array}$ & $\begin{array}{l}\text { Prospec } \\
\text { tive }\end{array}$ & $90 /-$ & $\begin{array}{l}\text { Revised } \\
\text { Tokuhashi }\end{array}$ & $\begin{array}{l}\text { Only } 33.4 \% \text { of } \\
\text { mean survival } \\
\text { predictability } \\
\text { reported }\end{array}$ \\
\hline $\begin{array}{l}\text { Papastefa } \\
\text { nou et al. } \\
{[33]}\end{array}$ & 2012 & $\begin{array}{l}\text { Prospec } \\
\text { tive }\end{array}$ & $52 /-$ & $\begin{array}{l}\text { Revised } \\
\text { Tokuhashi, } \\
\text { Tomita }\end{array}$ & $\begin{array}{l}\text { The Tokuhashi } \\
\text { score is more } \\
\text { valuable than the } \\
\text { Tomita score }\end{array}$ \\
\hline $\begin{array}{l}\text { Wang et } \\
\text { al. [34] }\end{array}$ & $\begin{array}{l}\text { April } \\
2012\end{array}$ & $\begin{array}{l}\text { Prospec } \\
\text { tive }\end{array}$ & $448 /-$ & $\begin{array}{l}\text { Tokuhashi } \\
\text { and } \\
\text { revised } \\
\text { Tokuhashi }\end{array}$ & $\begin{array}{l}\text { Both of the } \\
\text { systems showed } \\
\text { significant } \\
\text { predictive value }\end{array}$ \\
\hline $\begin{array}{l}\text { Aoude et } \\
\text { al. [35] }\end{array}$ & $\begin{array}{l}\text { June } \\
2014\end{array}$ & $\begin{array}{l}\text { Retrosp } \\
\text { ective }\end{array}$ & $128 /-$ & $\begin{array}{l}\text { Revised } \\
\text { Tokuhashi, } \\
\text { Tomita }\end{array}$ & $\begin{array}{l}\text { Both of the } \\
\text { systems are } \\
\text { useable, but the } \\
\text { Tokuhashi system } \\
\text { has better } \\
\text { accuracy }\end{array}$ \\
\hline $\begin{array}{l}\text { Petteys et } \\
\text { al. [36] }\end{array}$ & $\begin{array}{l}\text { March } \\
2015\end{array}$ & $\begin{array}{l}\text { Retrosp } \\
\text { ective }\end{array}$ & $30 /-$ & $\begin{array}{l}\text { Revised } \\
\text { Tokuhashi }\end{array}$ & $\begin{array}{l}\text { The Tokuhashi } \\
\text { score can be } \\
\text { useful }\end{array}$ \\
\hline
\end{tabular}

